\title{
Ultrastructural Distribution of the $\alpha 7$ Nicotinic Acetylcholine Receptor Subunit in Rat Hippocampus
}

\author{
Ruth Fabian-Fine, ${ }^{1,2}$ Paul Skehel, ${ }^{2}$ Mick L. Errington, ${ }^{2}$ Heather A. Davies, ${ }^{1}$ Emanuele Sher, ${ }^{3}$ \\ Michael G. Stewart, ${ }^{1}$ and Alan Fine ${ }^{2,4}$ \\ ${ }^{1}$ Department of Biological Sciences, The Open University, Milton Keynes, MK7 6AA, United Kingdom, ${ }^{2}$ Division of \\ Neurophysiology, National Institute for Medical Research, Mill Hill, London NW7 1AA, United Kingdom, ${ }^{2}$ Lilly Research \\ Centre, Eli Lilly and Co., Erl Wood Manor, Windlesham, Surrey GU20 6PH, United Kingdom, and ${ }^{4}$ Department of \\ Physiology and Biophysics, Dalhousie University Faculty of Medicine, Halifax, Nova Scotia B3H 4H7, Canada
}

Acetylcholine (ACh) is an important neurotransmitter in the mammalian brain; it is implicated in arousal, learning, and other cognitive functions. Recent studies indicate that nicotinic receptors contribute to these cholinergic effects, in addition to the established role of muscarinic receptors. In the hippocampus, where cholinergic involvement in learning and memory is particularly well documented, $\alpha 7$ nicotinic acetylcholine receptor subunits ( $\alpha 7 \mathrm{nAChRs)}$ are highly expressed, but their precise ultrastructural localization has not been determined. Here, we describe the results of immunogold labeling of serial ultrathin sections through stratum radiatum of area CA1 in the rat. Using both anti- $\alpha 7 \mathrm{nAChR}$ immunolabeling and $\alpha$-bungarotoxin binding, we find that $\alpha 7 \mathrm{nAChRs}$ are present at nearly all synapses in CA1 stratum radiatum, with immunolabeling present at both presynaptic and postsynaptic elements. Morphological considerations and double immunolabeling indicate that GABAergic as well as glutamatergic synapses bear $\alpha 7 \mathrm{nAChRs,} \mathrm{at} \mathrm{densi-}$ ties approaching those observed for glutamate receptors in CA1 stratum radiatum. Postsynaptically, $\alpha 7 \mathrm{nAChRs}$ often are distributed at dendritic spines in a perisynaptic annulus. In the postsynaptic cytoplasm, immunolabeling is associated with spine apparatus and other membranous structures, suggesting that $\alpha 7 \mathrm{nAChRs}$ may undergo dynamic regulation, with insertion into the synapse and subsequent internalization. The widespread and substantial expression of $\alpha 7 \mathrm{nAChRs}$ at synapses in the hippocampus is consistent with an important role in mediating and/or modulating synaptic transmission, plasticity, and neurodegeneration.

Key words: acetylcholine receptors; nicotine; dendritic spines; postsynaptic density; immuno-electron microscopy; glutamate; $G A B A ; A \beta_{1-42}$
Acetylcholine (ACh) is the major excitatory neurotransmitter in the peripheral nervous system. Ionotropic nicotinic receptors mediate postsynaptic excitatory responses at the neuromuscular junction, and there is evidence that nicotinic receptors may also act presynaptically to modulate acetylcholine release in the periphery (Wessler et al., 1992; Liang and Vizi, 1997). In the mammalian CNS, specific receptors for nicotinic ligands have been recognized for many years (Arimatsu et al., 1978; Dudai and Segal, 1978; Hunt and Schmidt, 1978; Segal et al., 1978), but only recently has evidence begun to emerge for their functional roles, including possible mediation of fast postsynaptic responses at certain brain sites (Zhang et al., 1993; Roerig et al., 1997; Chu et al., 2000) and modulation of release of various transmitters, including glutamate (Vidal and Changeux, 1993; McGehee et al., 1995; Gray et al., 1996), GABA (Lena et al., 1993), ACh (McGehee et al., 1995), and dopamine (Rapier et al., 1988). Nicotinic receptors constitute a heterogeneous family of ion channels. In the nervous system, nine different $\alpha$ subunits $(\alpha 2-\alpha 10)$ and three different $\beta$ subunits $(\beta 2-\beta 4)$ have been described. Most are as-

\footnotetext{
Received Feb. 21, 2001; revised June 13, 2001; accepted June 28, 2001.

This work was supported by the Medical Research Council and by grants from the Human Frontier Science Program (A.F.) and the Brain and Behavioural Sciences Research Council (108/BI 11211) (M.G.S.). We thank J.-A. Horne, E. Hirst, and Drs. T. V. P. Bliss, I. Burdett, and I. A. Meinertzhagen for helpful discussion.

Correspondence should be addressed to Dr. Ruth Fabian-Fine, Department of Psychology, Dalhousie University, Halifax, Nova Scotia B3H 4J1 Canada. E-mail: rfabian@is.dal.ca.

Copyright (C) 2001 Society for Neuroscience $0270-6474 / 01 / 217993-11 \$ 15.00 / 0$
}

sumed to form heteropentameric structures, with various combinations of $\alpha$ and $\beta$ subunits. There is also evidence in heterologous expression systems that some subunits, particularly $\alpha 7$, form homopentamers (Couturier et al., 1990; Schoepfer et al., 1990; Seguela et al., 1993). Nicotinic acetylcholine receptors containing $\alpha 7$ subunits ( $\alpha 7 \mathrm{nAChRs)}$ are, along with those containing the $\alpha 4 / \beta 2$ combination, the most abundant in brain. The distribution of these receptors is specific, with the $\alpha 7$ subunit, which is selectively bound by $\alpha$-bungarotoxin ( $\alpha \operatorname{Bgtx}$ ) (Chen and Patrick, 1997; Orr-Urtreger et al., 1997), abundant in particular cortical and subcortical areas (Bina et al., 1995) of the mammalian brain; conspicuous among these is the hippocampus (Dominguez del Toro et al., 1994). The $\alpha 7$ subunit appears to participate in numerous important processes, including modulation of release of several neurotransmitters, mediation of postsynaptic excitatory responses, long-term potentiation (LTP), and cognitive function (Hunter et al., 1994; Fujii et al., 2000; Mansvelder and McGehee, 2000) (for review, see Role and Berg, 1996; Wonnacott, 1997; Radcliffe et al., 1999; Levin and Rezvani, 2000).

Light microscopic immunostaining has revealed the presence of $\alpha 7 \mathrm{nAChRs}$ in both somatic and dendritic regions in all hippocampal areas (Dominguez del Toro et al., 1994). Hippocampal cells in culture were found to exhibit patchy $\alpha 7 \mathrm{nAChR}$ immunolabeling on somata and dendrites, colocalized with presynaptic markers (Barrantes et al., 1995; Zarei et al., 1999), but the identity of the labeled cells was unspecified, nor was it possible at the light microscopic level to establish the presynaptic versus 

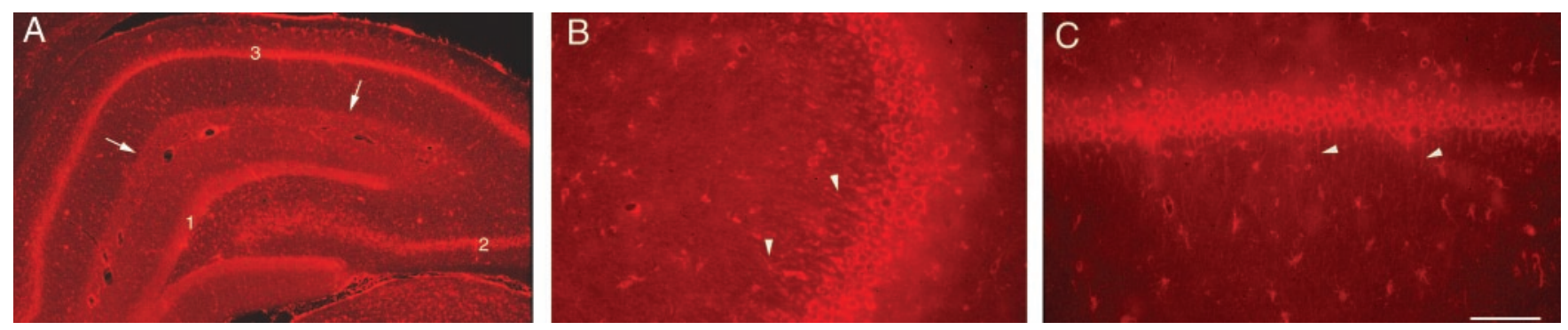

Figure 1. Distribution of $\alpha 7 \mathrm{nAChR}$-LIR in rat hippocampus. $A$, Low magnification micrograph of the hippocampal formation shows that all areas display $\alpha 7$ nAChR-LIR. The strongest immunoreactivity is present in the cell body layers (1, dentate gyrus; 2 , CA3; 3, CA1) and in the molecular layer of the dentate gyrus (arrows). B, C, Higher magnification of the CA3 $(B)$ and CA1 $(C)$ regions show that the apical dendrites of the pyramidal cells (arrowheads) display $\alpha 7 \mathrm{nAChR}$-LIR. Scale bar: $A, 1 \mathrm{~mm} ; B, C, 170 \mu \mathrm{m}$.

postsynaptic nature of the labeling. Electron microscopic (EM) analysis of ${ }^{125} \mathrm{I}-\alpha$ Bgtx binding provided evidence for $\alpha 7 \mathrm{nAChRs}$ at hippocampal synapses (Hunt and Schmidt, 1978), but the large grain radius and relative insensitivity of the method prevented firm conclusions about incidence or distribution of the $\alpha$ Bgtx binding sites. Full understanding of the varied and subtle functional roles recently attributed to $\alpha 7 \mathrm{nAChRs}$ in the hippocampus (Radcliffe et al., 1999) will require high-resolution analysis of the subcellular distribution of this subunit. To this end, we have performed light and electron microscopic immunostaining of CA1 stratum radiatum, and here report that $\alpha 7$ receptors are highly abundant at almost all synapses in this region. The intensity of the signal suggests that the importance of $\alpha 7$-mediated nicotinic cholinergic signaling may be far greater than is currently recognized.

\section{MATERIALS AND METHODS}

Light microscopic $\alpha 7 n A C h R$ immunolabeling. Intact brain preparations were obtained from two adult male Sprague Dawley rats. Animals were anesthetized with urethane $(1.5 \mathrm{gm} / \mathrm{kg}$, i.p. $)$ and perfused over $\sim 20 \mathrm{~min}$ with $200 \mathrm{ml}$ of $4 \%$ paraformaldehyde (PFA) $/ 0.3 \%$ glutaraldehyde (GA) in PBS (0.1 M, pH 7.2). After dissection the brains were immersed in the same fixative for $2 \mathrm{hr}$ and embedded in $7 \%$ Agarose. Vibratome sections $30 \mu \mathrm{m}$ thick were cut transversely through the brain using a Leica VT1000S and rinsed in PBS $(4 \times 10 \mathrm{~min})$. Sections containing the hippocampal formation were then incubated in $1 \%$ glycine in PBS to quench residual reactive aldehyde groups, washed in PBS $(2 \times 10 \mathrm{~min})$, permeabilized in $0.1 \%$ saponin (S2149; Sigma, St. Louis, MO)/PBS for $15 \mathrm{~min}$, and incubated with the primary monoclonal anti- $\alpha 7 \mathrm{nAChR}$ antibody Mab 306 (M220, Sigma) (Schoepfer et al., 1990) at $4^{\circ} \mathrm{C}$ overnight. The antibody was diluted 1:3000 in an incubation medium (IM) consisting of PBS with $1 \%$ bovine serum albumin (A4503, Sigma), 5\% normal goat serum, $0.5 \%$ cold water fish skin gelatin (G7765, Sigma), and $0.01 \%$ saponin. After incubation, preparations were rinsed thoroughly in PBS. To detect anti- $\alpha 7 \mathrm{nAChR}$ antibody binding, a secondary goat anti-mouse antibody coupled to the fluorochrome Cy3 (Stratech Scientific, Luton, UK; 115-165-003; 1:500 in IM at $4^{\circ} \mathrm{C}$ overnight) was used. Preparations were then washed in PBS $(6 \times 1 \mathrm{hr})$, mounted in Mowiol 4-88 (475904, Calbiochem, La Jolla, CA) on glass slides, and examined using a Zeiss Axiophot microscope with epifluorescence optics. Red Cy3-immunofluorescence was detected using a standard rhodamine filter set. Preparations were immediately photographed on color slide film (Ektachrome 400).

Light microscopic labeling for synaptophysin and $\alpha$ Bgtx. Hippocampal preparations were obtained from two adult male Sprague Dawley rats. Animals, anesthetized as above, were perfused over $\sim 10$ min with $200 \mathrm{ml}$ of freshly prepared 4\% PFA in PBS. Brains were removed, embedded in 7\% Agarose, and $20 \mu \mathrm{m}$ vibratome sections obtained as above. After permeabilization with $0.01 \%$ saponin in IM (30 min), sections were incubated in IM containing a monoclonal anti-synaptophysin antibody (1:120; SY38, 902322; Boehringer Mannheim, Mannheim, Germany) overnight at $4^{\circ} \mathrm{C}$. After washing in PBS $(5 \times 1 \mathrm{hr})$ and $0.01 \%$ saponin in $\mathrm{IM}$, preparations were incubated overnight at $4^{\circ} \mathrm{C}$ in IM containing a secondary goat anti-mouse antibody coupled to $\mathrm{Cy} 3$ (1:500; see above) and Alexa488-conjugated $\alpha \operatorname{Bgtx}$ (1:500; B13422; Molecular Probes). After thorough rinsing in PBS $(4 \times 1 \mathrm{hr})$, slices were mounted in Mowiol and examined with a Leica TCS NT confocal microscope using standard fluorescein and rhodamine filter combinations.

Postembedding immunogold labeling for electron microscopy. Freezesubstituted tissue was used to preserve greater immunoreactivity of the tissue and achieve maximum staining intensity. Three adult (all 22 months old) CFHB male rats were anesthetized with Sagatal and perfused through the heart with $50 \mathrm{ml}$ of $0.9 \%$ saline followed by $250 \mathrm{ml} 0.1$ $\mathrm{M}$ phosphate buffer, $\mathrm{pH} 7.4$, containing $4 \%$ paraformaldehyde, $0.05 \%$ glutaraldehyde, and $0.2 \%$ picric acid (Somogyi and Takagi, 1982). Hippocampus was dissected immediately, and $\sim 0.5 \mathrm{~mm}$ slabs were cut by hand from the dorsal part, soaked in PB for $15 \mathrm{~min}$, and then immersed in $0.125 \mathrm{M}$ triethanolamine hydrochloride in $\mathrm{PB}$ for $30 \mathrm{~min}$ to quench unreacted aldehydes. The tissue slabs were cryoprotected over $2 \mathrm{hr}$ in increasing concentrations of glycerol in PBS to $30 \%$ and then impactfrozen on a polished copper mirror at $-193^{\circ} \mathrm{C}$ in a Leica MM80 impact freezer. Frozen slabs were freeze-substituted in a Leica AFS automatic freeze substitution system in methanol with $0.5 \%$ uranyl acetate for $24 \mathrm{hr}$ at $-85^{\circ} \mathrm{C}$, rinsed in methanol, and the temperature raised to $-50^{\circ} \mathrm{C}$ before infiltration and embedding in Lowicryl HM 20 (R1034; Agar Scientific, Stansted, England). The resin was polymerized at $-50^{\circ} \mathrm{C}$ by exposure to ultraviolet light. Serial ultrathin sections $(50 \mathrm{~nm})$ were cut with a Reichert Ultracut and collected on pioloform-coated single-slot nickel grids. To treat all sections identically and to prevent tearing during the labeling procedure, grids were mounted in a grid support plate (16705698; Leica Microsystems, Milton Keynes, UK). Sections were wetted in PBS for $30 \mathrm{~min}$ and preincubated in IM for $30 \mathrm{~min}$ at room temperature. Sections were then incubated with the monoclonal anti- $\alpha 7$ nAChR antibody (see above; 1:4000 in IM) overnight at $4^{\circ} \mathrm{C}$ followed by $1 \mathrm{hr}$ at $37^{\circ} \mathrm{C}$. After thorough washing in PBS and preincubation in IM (30 $\mathrm{min}$ ), the secondary antibody (goat anti-mouse coupled to $10 \mathrm{~nm}$ gold particles; G7402; Sigma) was applied at a dilution of 1:100 for $4 \mathrm{hr}$ at $37^{\circ} \mathrm{C}$. Preparations were washed subsequently in IM (10 min) and PBS $(3 \times 10 \mathrm{~min})$ before final rinsing in double-distilled water.

For the double labeling of (1) glutamate and $\alpha 7 \mathrm{nAChR}$, (2) GABA and $\alpha 7 \mathrm{nAChR}$, or (3) dual epitopes of $\alpha 7 \mathrm{nAChR}$, the following antibodies were used: (1) rabbit anti-glutamate (1:20,000 in IM; G6642; Sigma) detected with goat anti-rabbit $10 \mathrm{~nm}$ gold plus mouse anti- $\alpha 7$ $\mathrm{nAChR}(1: 4000$ in IM) detected with goat anti-mouse $5 \mathrm{~nm}$ gold (EM.GAM5; British Biocell, Cardiff, Wales, UK); (2) rabbit anti-GABA (1:4000 in IM; A2052; Sigma) detected with goat anti-rabbit $10 \mathrm{~nm}$ gold plus mouse anti- $\alpha 7 \mathrm{nAChR}$ (1:4000 in IM) detected with goat anti-mouse $5 \mathrm{~nm}$ gold, or (3) rabbit anti- $\alpha 7 \mathrm{nAChR}$ (1:100 in IM; SC5544; Santa Cruz Biotechnology, CA) detected with goat anti-rabbit $10 \mathrm{~nm}$ gold plus mouse anti- $\alpha 7 \mathrm{nAChR}$ (1:4000 in IM) detected with goat anti-mouse 5 $\mathrm{nm}$ gold. All secondary gold-conjugated antibodies were used at a dilution of 1:100 in IM. The sections were contrasted with uranyl acetate (5 min) and Reynold's lead citrate (50 sec) according to standard EM methods. The preparations were examined using JEOL JEM-100 CX and JEOL JEM-1010 electron microscopes.

For $\alpha$ Bgtx labeling, ultrathin sections were incubated in IM containing biotin-XX-conjugated $\alpha \operatorname{Bgtx}$ (1:300 for $4 \mathrm{hr}$ at room temperature; B-1196; Molecular Probes). After rinsing in PBS, sections were incubated overnight at $4^{\circ} \mathrm{C}$ in IM containing mouse anti-biotin antibody (1:250; A-11242; Molecular Probes). For detection of the mouse anti-biotin antibody, a goat anti-mouse antibody coupled to $10 \mathrm{~nm}$ gold was used 
A

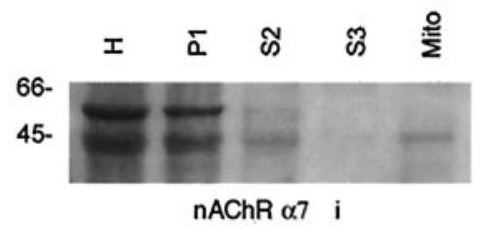

$66-$

45 -

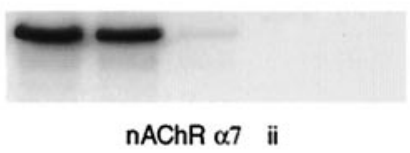

66-

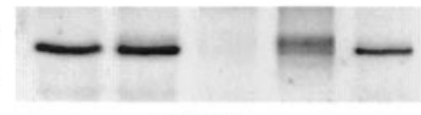

Hsp-60

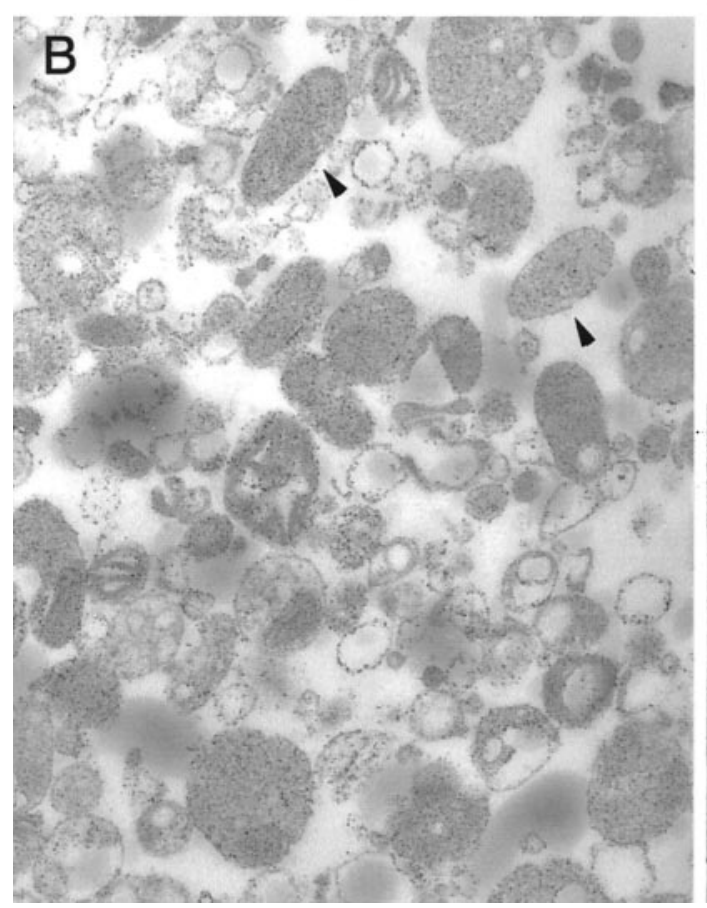

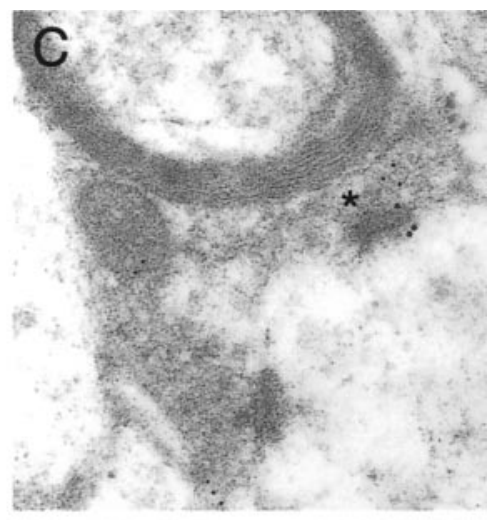

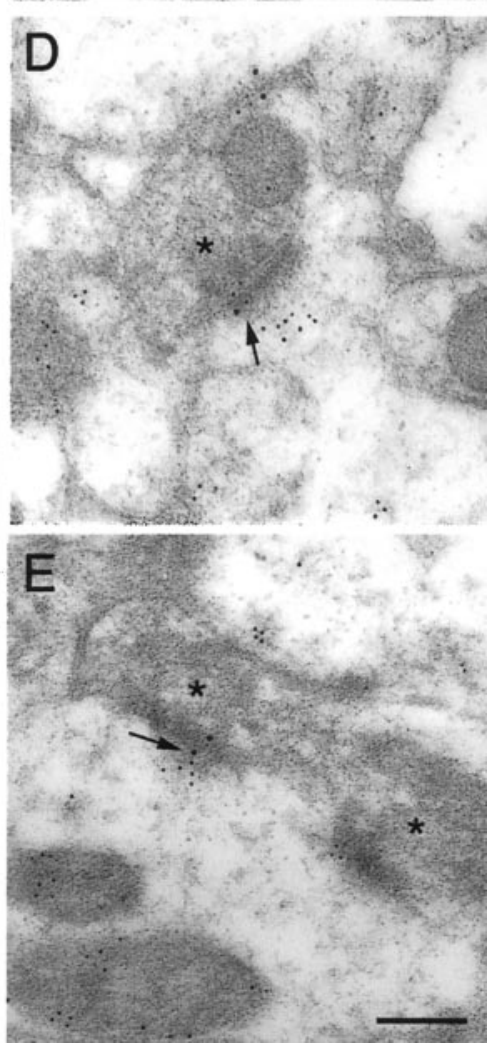

Figure 2. A, The specificity of the mitochondrial labeling seen with immuno-electron microscopy was addressed by Western blot analysis of hippocampal proteins. The monoclonal anti- $\alpha 7$ nAChR antibody M220 labels two bands in the homogenate and low-speed pellet, with molecular masses of 56 and $46 \mathrm{kDa}(n A C h R \alpha 7, i)$. The $56 \mathrm{kDa}$ protein, which corresponds to the $\alpha 7$ nAChR subunit, is not present in the mitochondrial fraction (Mito). The $46 \mathrm{kDa}$ immunoreactivity is sensitive to binding conditions and is not present when the binding buffer contains 3\% nonfat milk powder $(n A C h R \alpha 7, i i)$. The mitochondrial protein Hsp-60 is enriched in the mitochondrial fraction. $B$, Electron micrographs of the mitochondrial fraction tested in $A$ demonstrate that these organelles were highly enriched in the pellet (arrowheads). $C-E$, Double labeling of different epitopes of $\alpha 7 \mathrm{nAChR}$ with the monoclonal antibody M220 (5 $\mathrm{nm}$ particles) and a polyclonal antiserum SC5544 (10 $\mathrm{nm}$ particles) demonstrates that both reagents label synaptic sites (*) and are often colocalized (arrows). Scale bar: $B, 370 \mathrm{~nm} ; C-E, 280 \mathrm{~nm}$.
(1:100; $4 \mathrm{hr}$ at $37^{\circ} \mathrm{C}$; see above). The labeling in control preparations in which the biotin-XX-conjugated $\alpha \operatorname{Bgtx}$ was omitted did not exceed background intensity and revealed no evidence that the biotin binds unspecifically to synaptic sites.

Mitochondria preparation and Western blot analysis. Mitochondria were prepared from the hippocampus of four $115 \mathrm{gm}$ male Sprague Dawley rats, according to standard methods (Løvtrup and Zelander, 1962). Briefly, hippocampus was homogenized on ice in $10 \mathrm{vol}$ of $0.44 \mathrm{~m}$ sucrose, $10 \mathrm{~mm} \mathrm{HEPES}$, and $1 \mathrm{~mm} \mathrm{MgCl}_{2}$. The homogenate was then centrif uged at $2000 \mathrm{rpm}(400 \times \mathrm{g})$ for $10 \mathrm{~min}$ at $4^{\circ} \mathrm{C}$ in a Beckman JA-20. The supernatant was removed, leaving $\mathrm{P} 1$, and centrifuged again at 14,000 $\operatorname{rpm}(17,500 \times g)$ for 15 min under the same conditions. The resulting supernatant S2 was removed, and the pellet was resuspended in ice-cold homogenization buffer and centrifuged again at $9000 \mathrm{rpm}(7000 \times \mathrm{g})$ for 15 min to generate a supernatant S3 and a pellet enriched for mitochondria. This operation was repeated twice more to wash the mitochondrial fraction. Equivalent amounts of each fraction and the initial homogenate were analyzed by Western blot analysis. Proteins were separated by SDS-PAGE as described previously (Schägger and von Jagow, 1987) using a $10 \%$ separating gel, and transferred to Immobilon-P by electroblotting. Membranes were blocked in either 2\% (w/v) BSA (Fraction V, 735086, Boehringer Mannheim), 0.05\% (v/v) Nonidet P40 (BDH, Poole UK) in PBS, or $3 \%$ nonfat milk powder, $0.05 \%(\mathrm{v} / \mathrm{v})$ NP40 in PBS. Primary antibodies were applied in the same buffer at dilutions of
1:10,000 for anti- $\alpha 7 \mathrm{nAChR}$ (M220) and 1:30,000 for anti-Hsp60 (SPA804; StressGen, Victoria British Columbia, Canada). Immunoreactivity was detected using HRP-conjugated donkey anti-rabbit (711-035-152; Stratech Scientific, Luton, UK) or anti-mouse (715-035-150; Stratech Scientific) serum at 1:10,000 and ECL (RPN 2106, Amersham Pharmacia Biotech, Little Chalfont, UK).

Controls. The specificity of the mouse anti- $\alpha 7 \mathrm{nAChR}$ antibodies used here has been described previously (Schoepfer et al., 1990; Dominguez del Toro et al., 1994). Specificity of antibody binding was confirmed by immunoblots and by the absence of immunolabeling in preparations from which primary antibodies were omitted. The anti-synaptophysin antibody used here is well characterized and is known to bind selectively to presynaptic sites (Wiedenmann and Franke 1985). Additional controls were as described below.

Image analysis and processing. Because sections from all three animals processed for electron microscopy showed similar labeling intensity, randomly selected serial sections from all animals were combined for analysis. Gold particles at synaptic profiles were counted manually on printed electron micrographs from 14 series (10,000× magnification), each consisting of three serial sections. For the purpose of this study, structures considered to be synapses satisfied the following criteria: (1) presence of a synaptic cleft; (2) accumulation of synaptic vesicles in the presynaptic terminal close to the synaptic cleft; and (3) presence of a postsynaptic density in the postsynaptic profile. According to the appear- 

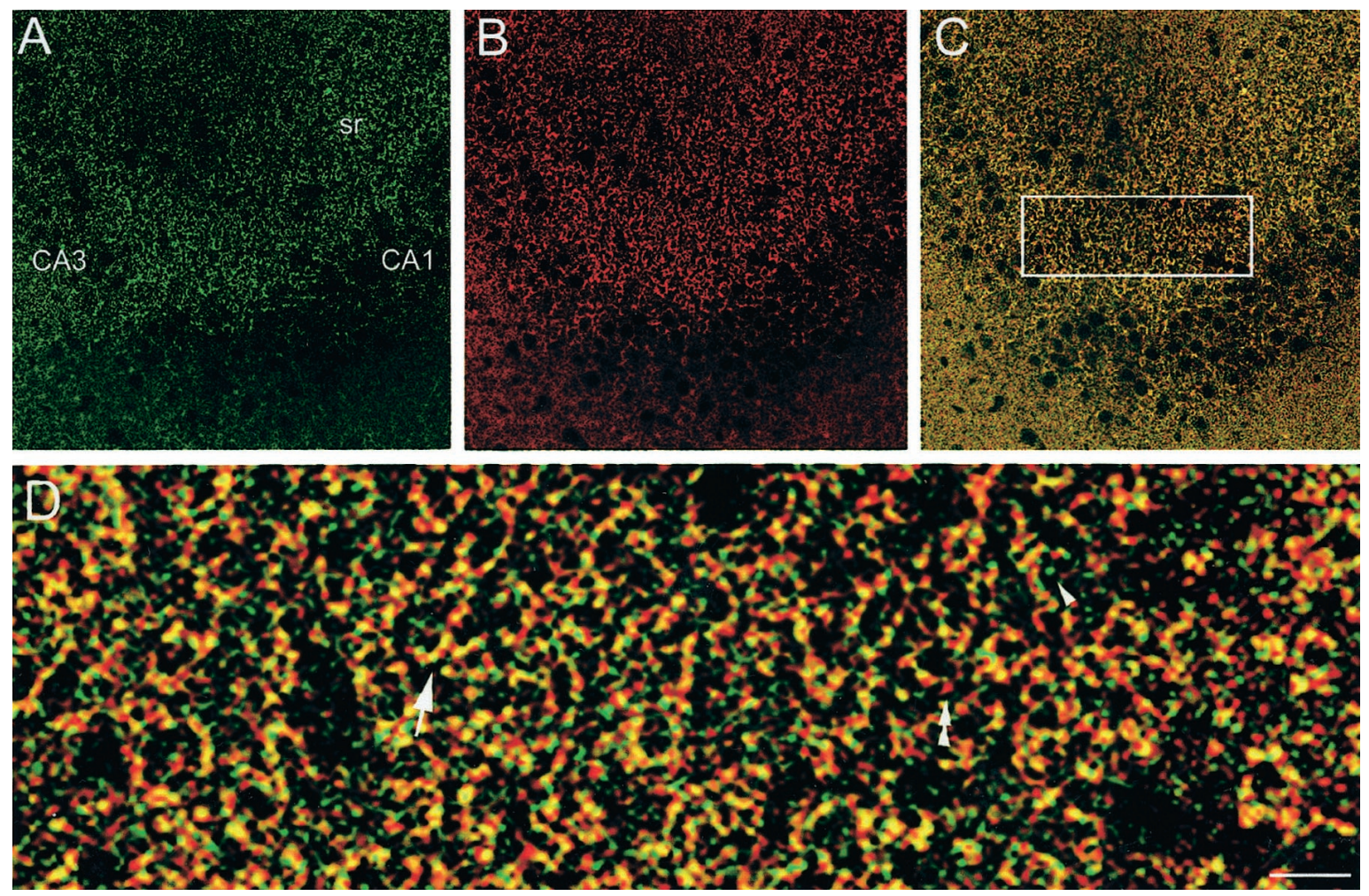

Figure 3. A-C, Light microscopic double labeling for $\alpha \operatorname{Bgtx}$ ( green) and synaptophysin (red) demonstrates the abundance and substantial correspondence of both labeled sites. $D$, Higher magnification of the area outlined in $C$ reveals the predominant colocalization (arrow) or close apposition of both labeled sites. A small proportion of synaptophysin-labeled sites (double arrowhead) and a fraction of $\alpha$ Bgtx-labeled sites (arrowhead) show no colocalization. Scale bar: $A-C, 130 \mu \mathrm{m} ; D, 30 \mu \mathrm{m}$.

ance of the postsynaptic density, two different synapse types have been distinguished in the vertebrate CNS (Gray, 1959; Colonnier, 1968). The first type (type 1 or "asymmetrical synapse") has an extensive postsynaptic density and a population of large, round, electron-lucent vesicles in the presynaptic profile. Type 2 ("symmetrical synapses") are characterized by a less conspicuous postsynaptic density and a presynaptic population of small, pleomorphic, electron-lucent vesicles. It is generally accepted that glutamatergic synapses have asymmetric morphology, whereas GABAergic synapses are symmetric. Complete counts of all gold particles at each synapse would require full three-dimensional reconstruction of each synapse, a prohibitively time-consuming task. As a useful approximation that largely eliminates false-negative (unlabeled) synapses, we analyzed sets of three serial sections. All synapses in randomly selected fields of view that were present throughout all three serial sections were counted. For presentation, micrographs and slides were digitized at high resolution using a Mustek flatbed scanner or a Nikon LS-1000 slide scanner. Contrast and brightness were optimized in Adobe Photoshop 5.0.

Statistical analysis. Gold particle incidence was compared to determine whether the $\alpha 7 \mathrm{nAChR}$ immunolabeling over synaptic membranes was significantly higher than background labeling. Gold particles were counted over the synaptic membranes identified in all serial sections. The actual sampled region was the synaptic cleft plus the adjoining 30-nmwide presynaptic and postsynaptic zones, because the separation between a labeled epitope and a gold particle attached to a secondary antibody can extend up to $28 \mathrm{~nm}$ (Matsubara et al., 1996). These counts were compared with the number of gold particles over equivalent areas of regions where no labeling was expected, such as myelin. Because particle counts were not normally distributed, a Welch $t$ test was used for comparisons. The sampled synaptic area for each synapse was estimated by multiplying the total sampled length of the synaptic cleft over the three serial sections by the section thickness. Linear regression analysis was performed to examine possible correlation of the number of gold particles per synapse with the synaptic area.
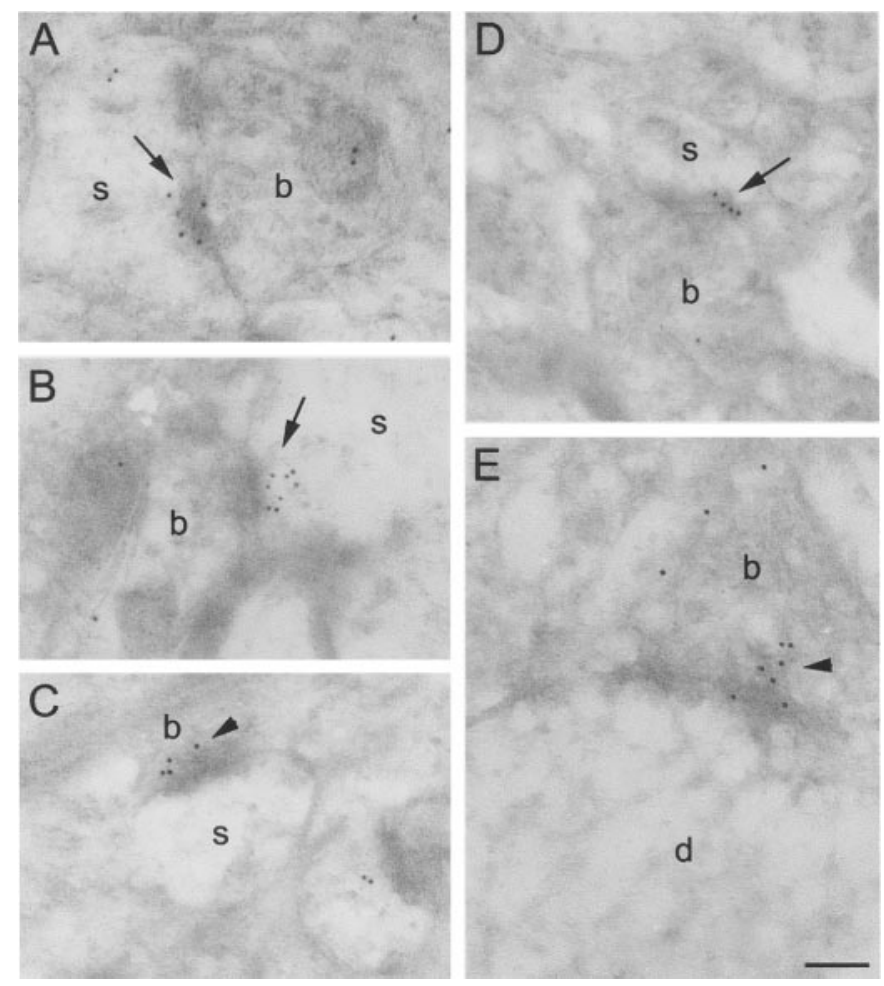

Figure 4. Electron micrographs of the CA1 stratum radiatum area in $\alpha$ Bgtx-labeled intact brain preparations. $A-E$, Labeling for $\alpha$ Bgtx is present at presynaptic (arrowheads) and postsynaptic sites (arrows). b, Presynaptic boutons; $s$, dendritic spines. Scale bar, $200 \mathrm{~nm}$. 

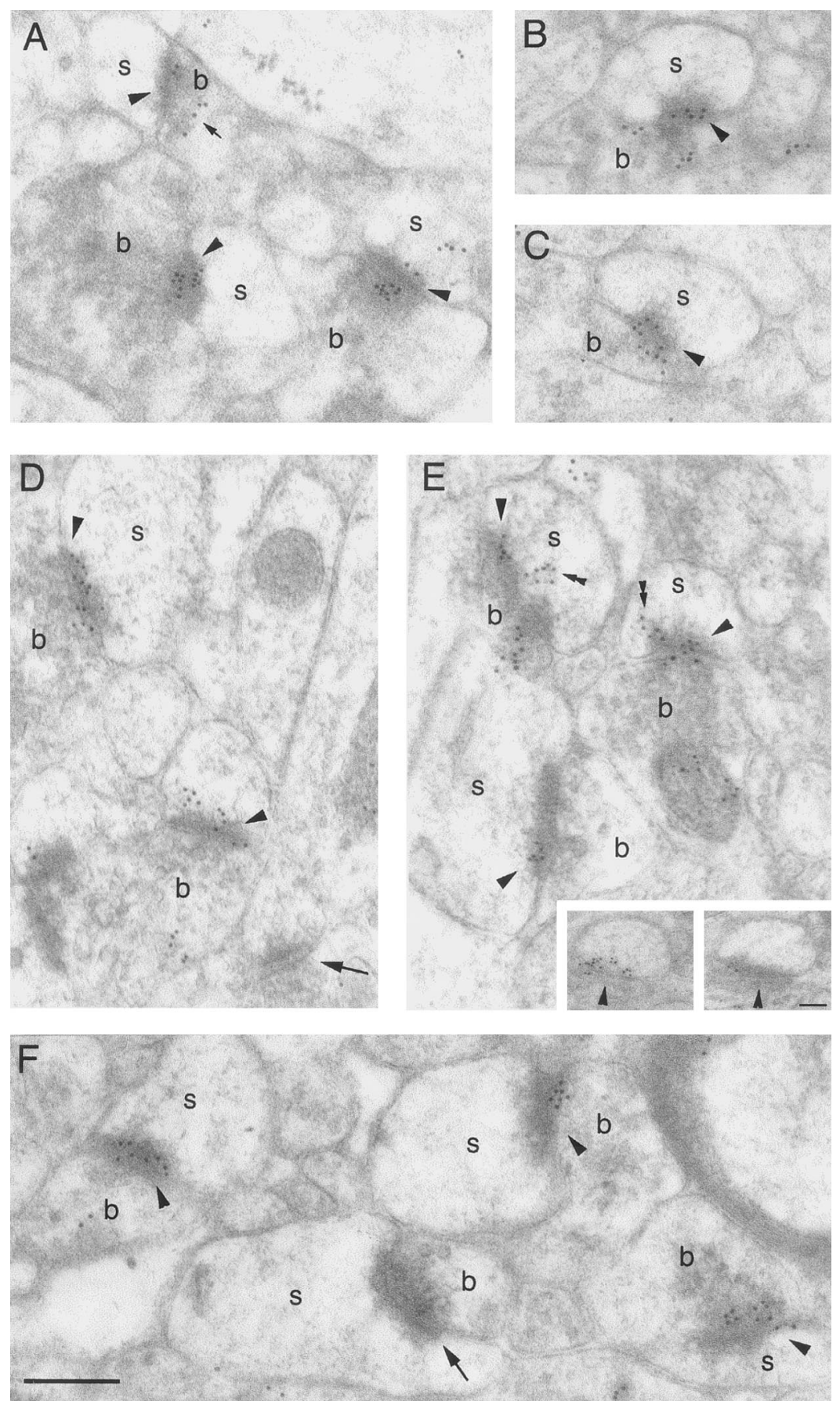

Figure 5. Electron micrographs of the CA1 stratum radiatum region in anti- $\alpha 7 \mathrm{nAChR}$-labeled intact brain preparations. $A-F$, Most synaptic contacts contain numerous gold particles at synaptic membranes (arrowheads). Gold particles are also found at presynaptic vesicles (small arrow) and attached to membranous structures in the postsynaptic cytoplasm (double arrowheads). Inset, Gold particles were often found at nonsynaptic membranes at positions corresponding to synapses in adjacent sections (arrowheads), indicating a perisynaptic localization of the $\alpha 7 \mathrm{nAChR}$ subunits. $b$, Presynaptic boutons; $s$, dendritic spines. Scale bar: $A-F, 200 \mathrm{~nm}$; inset, $90 \mathrm{~nm}$.

\section{RESULTS}

\section{Light and electron microscopic immunolabeling demonstrates that the $\alpha 7 \mathrm{nAChR}$ subunit is present in cell bodies and processes of hippocampal neurons}

Light microscopic immunolabeling of the hippocampal formation revealed diffuse $\alpha 7 \mathrm{nAChR}$-like immunoreactivity $(\alpha 7 \mathrm{nAChR}$ LIR) throughout cell bodies and cell processes of neurons in the dentate gyrus and CA3 and CA1 regions (Fig. 1). Immunoreactivity throughout the molecular layer of the dentate gyrus and in the cell body layers of all regions was relatively strong and easily recognizable at low magnification (Fig. $1 A$ ). Immunoreactivity in the dendritic fields of CA3 and CA1 was weaker, but clearly visible at higher magnification in Figure $1, B$ and $C$. To determine the precise location of the $\alpha 7 \mathrm{nAChRs}$, we performed postembedding EM immunolabeling. Synaptic contacts were heavily labeled, as were membranous structures within the presynaptic and postsynaptic cytoplasm. Labeling was also present at mitochondria (Fig. 2); to determine whether this labeling represented authentic $\alpha 7 \mathrm{nAChRs}$ or cross-reactivity of the antibody with other protein(s) present in mitochondria, we performed Western blot analysis on subcellular fractions of brain homogenates. Our results demonstrate that the monoclonal antibody M220 recognizes two bands in crude homogenates, one of $\sim 56 \mathrm{kDa}$ (corresponding to the $\alpha 7 \mathrm{nAChR}$ ) and one of $44 \mathrm{kDa}$ (Fig. $2 A$ ). Only the $44 \mathrm{kDa}$ band was present in the purified mitochondrial fraction. That this fraction contained mainly mitochondria was con- 

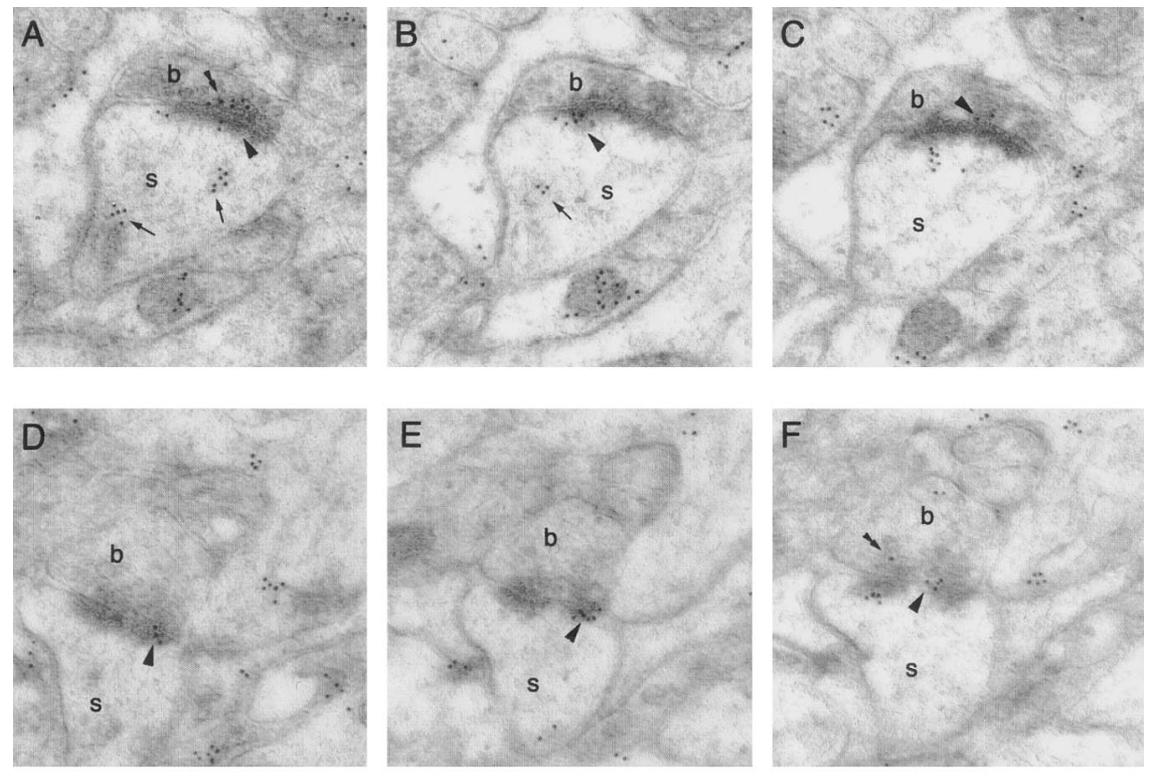

Figure 6. Electron micrographs of serial sections through anti- $\alpha 7 \mathrm{nAChR}$ labeled synaptic contacts in CA1 stratum radiatum. $A-I$, Some synaptic contacts show persistent labeling at synaptic membranes throughout all serial sections $(A-C, D-F$, arrowheads), whereas others lack synaptic labeling in at least one of the sections $(G-I)$. Labeling is found at presynaptic vesicles (double arrowheads) and at vesicular structures in the postsynaptic cytoplasm (arrows). $b$, Presynaptic boutons; $s$, postsynaptic spines. Scale bar: $A-I, 250 \mathrm{~nm}$.
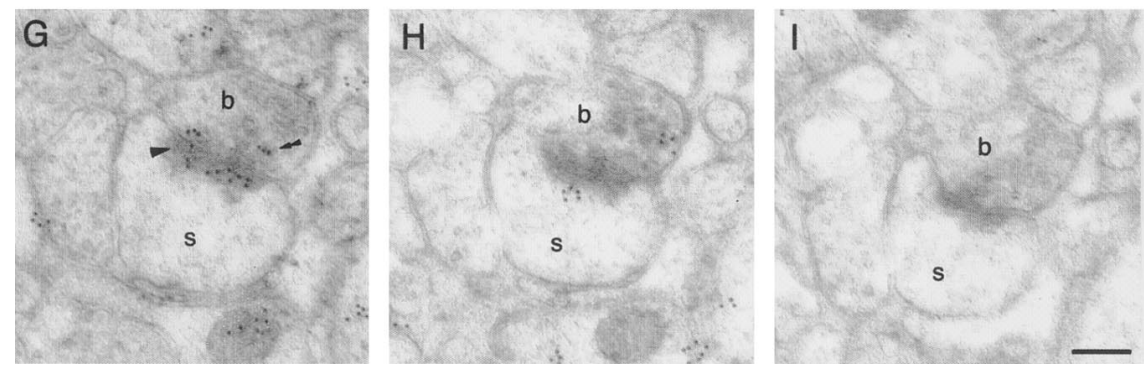

\section{Table 1. Quantitative parameters of serial section analysis of immunogold labeling for $\alpha 7 \mathrm{nAChRs}$ in CA1 stratum radiatum \\ Number of synapses evaluated (3 serial sections per synapse) \\ $158(100 \%)$ in 12 series \\ Number of synapses with labeled synaptic membranes in at least one of the three serial sections $151(96 \%)$ \\ Number of synapses with unlabeled synaptic mem- branes in all three serial sections \\ Number of synapses with labeled presynaptic sites (excluding the synaptic membrane) in at least one of the three serial sections \\ Number of synapses with labeled postsynaptic sites (excluding the synaptic membrane) in at least one of the three serial sections \\ $114(71 \%)$ \\ Number of background areas evaluated \\ 373 in 12 series}

firmed by its enrichment in the mitochondrial marker, Hsp-60 (Fig. $2 A$ ), and by ultrastructural investigation of the fraction (Fig. $2 B)$. We were able to eliminate the $44 \mathrm{kDa}$ band in Western blots using 3\% nonfat milk powder in the blocking medium (Fig. 2A) (see Materials and Methods). This blocking procedure, however, was not compatible with immuno-electron microscopy. To confirm the specificity of $\alpha 7 \mathrm{nAChR}$ immunolabeling, we performed two independent tests: (1) double labeling using the monoclonal antibody (M220) and a polyclonal antiserum (SC5544) raised against a larger epitope of the $\alpha 7$ subunit (polyclonal: amino acids 367-502; monoclonal: amino acids 380-400); and (2) light and electron microscopic labeling for $\alpha \mathrm{Bgtx}$. Figure $2 C-E$ demonstrate that both antibodies directed against the $\alpha 7$ subunit labeled synaptic contacts, frequently colocalizing at both presynaptic and postsynaptic sites. As shown in Figure 2, $D$ and $E$ ( $5 \mathrm{~nm}$ particles), the monoclonal antibody yielded stronger labeling, and only the monoclonal antibody labeled mitochondria (Fig. 2C-E).

The presence of $\alpha 7 \mathrm{nAChR}$ at synaptic sites was further confirmed by $\alpha$ Bgtx binding. As demonstrated in Figure 3, light microscopic double labeling for $\alpha \mathrm{Bgtx}$ and synaptophysin revealed abundant expression of both epitopes in hippocampal synaptic zones, often in close apposition. In keeping with previous findings (Hunt and Schmidt, 1979), $\alpha$ Bgtx binding was seen only occasionally throughout neuronal cell bodies; this difference compared with the pattern of anti- $\alpha 7 \mathrm{nAChR}$ immunolabeling may reflect the post-translational processing required for $\alpha \mathrm{Bgtx}$ binding (Chen et al., 1998; Aztiria et al., 2000) but not for binding of the monoclonal antibody directed against the peptide epitope. Ultrastructural investigation of hippocampal tissue labeled for $\alpha$ Bgtx revealed widespread presynaptic and postsynaptic labeling (Fig. 4) that, although less intense than the labeling observed with the anti- $\alpha 7 \mathrm{nAChR}$ antibody, was qualitatively similar in distribution, confirming that the synaptic immunolabeling reflects the presence of authentic $\alpha 7$ nAChRs.

\section{Most synapses in CA1 stratum radiatum display a7 nAChR-LIR}

The ultrastructural investigation of dentate gyrus and CA1 and CA3 regions revealed $\alpha 7 \mathrm{nAChR}-\mathrm{LIR}$ at synaptic sites in all hippocampal areas (Fig. 5). Gold particles were located mainly (1) at the postsynaptic density, (2) within the synaptic cleft, (3) in the postsynaptic cytoplasm (Figs. 5-7), and (4) at presynaptically located vesicles, often located in close proximity to the synaptic 
A

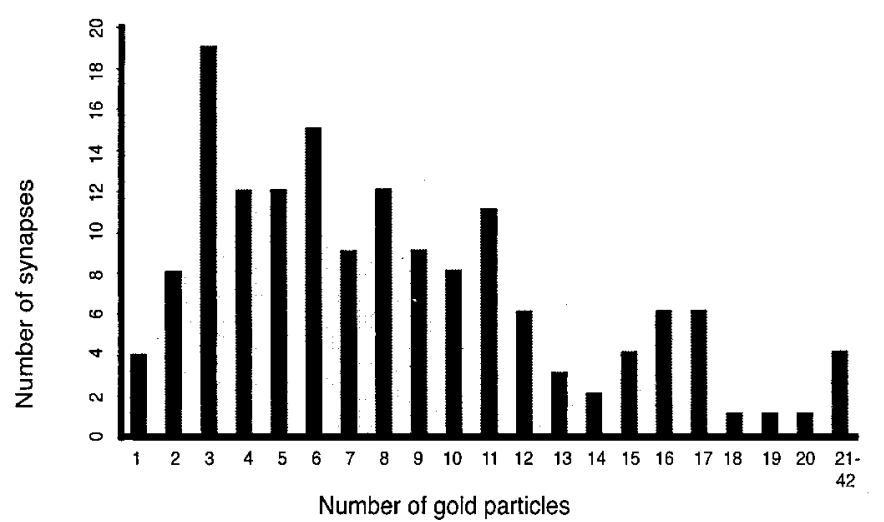

B
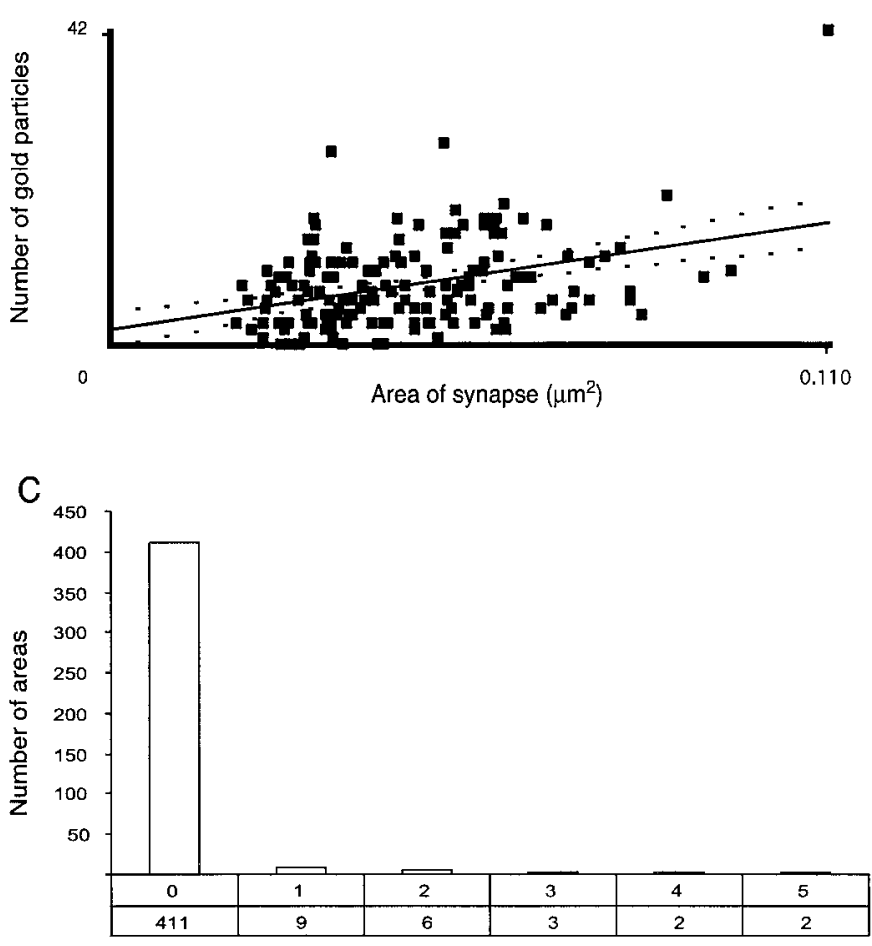

Number of gold particles over evaluated background areas $\left(0.42 \mu \mathrm{m}^{2} /\right.$ area $)$

Figure 7. Quantitative analysis of CA1 stratum radiatum synapses treated with a monoclonal anti- $\alpha 7 \mathrm{nAChR}$ antibody. $A$, Frequency histogram of total number of gold particles lying over the synaptic membrane, measured over three serial sections through each synaptic profile. $B$, Scatter plot of total number of gold particles lying over the synaptic membrane versus total sampled area of the synapse for each of the 158 synapses investigated. The particle number is weakly but significantly correlated with synaptic area (solid line, linear regression slope; slope significantly different from zero, $p<0.0001$; correlation coefficient $r=$ 0.372 ; dotted lines, $95 \%$ confidence limits; runs test for deviation from linearity, $p=0.689$, not significant.). $C$, Frequency histogram of gold particles over background areas equivalent to those measured for synapses, demonstrating that background areas were largely devoid of labeling. Beneath each bar of the histogram, the top number indicates the number of gold particles per area, and the bottom number indicates the number of areas represented by the individual bars.

membrane but $>30 \mathrm{~nm}$ apart from it (indicating that the epitope is located at the vesicles rather than the synaptic membrane). It is not clear whether the latter are synaptic vesicles or specialized transport vesicles. Labeled synapses were present at both den-
Table 2. Serial section analysis of synaptic immunogold labeling for $\alpha 7$ nAChRs

Number of gold particles per synapse

Range of gold particles per synapse

Synaptic area $\left(\mu \mathrm{m}^{2}\right)$

Particle density over synapses

$\left(\right.$ per $\left.\mu \mathrm{m}^{2}\right)$

Particle density over background

$\left(\right.$ per $\left.\mu \mathrm{m}^{2}\right)$

$8.038 \pm 0.467($ mean $\pm \mathrm{SEM})$

$0-42$

$0.046 \pm 0.001$

$184.01 \pm 10.15^{*}$

$2.70 \pm 0.78^{*}$

dritic spines and shafts. We determined the percentage of synapses labeled in the CA1 stratum radiatum region by serial section analysis (Fig. 6, Table 1), because gold particles may not be present in every section through a $\alpha 7 \mathrm{nAChR}$-LIR synapse, so that observations on single sections will underestimate the true incidence of labeled structures. For each of the 158 synapses evaluated in this study, three serial sections were analyzed. A synapse was considered immunoreactive for $\alpha 7 \mathrm{nAChRs}$ if one of the three sections showed at least one gold particle within $\sim 30 \mathrm{~nm}$ of the synaptic cleft to cover the possible separation between a labeled epitope and a gold particle attached to a secondary antibody (see above). The extent of this separation also rendered it impossible to ascertain whether gold particles within the synaptic cleft represented binding to the presynaptic or postsynaptic membrane; therefore, gold particles found within $30 \mathrm{~nm}$ of the synaptic cleft were classed together as labeling at synaptic membranes.

As summarized in Tables 1 and 2, 96\% of synapses displayed $\alpha 7 \mathrm{nAChR}-\mathrm{LIR}$ at synaptic membranes, with an average of $8.04 \pm 0.47$ gold particles per synapse, evaluated over the three serial sections. The mean synaptic area $\left(0.046 \pm 0.001 \mu \mathrm{m}^{2}\right)$ was similar to values obtained by complete serial sectioning through synapses in CA1 stratum radiatum [e.g., $0.040-0.046 \mu \mathrm{m}^{2}$ in Racca et al. (2000)]. The gold particle density over synaptic areas was significantly higher than the particle density over control areas (Fig. 7, Table 2) where no $\alpha 7$ nAChRs are expected, such as myelin. The range of gold particles per labeled synapse varied from 1 to 42, with most synapses bearing between 2 and 17 particles (Fig. $7 A$, Table 2). A part of this variance is most likely a consequence of the different (sampled) synaptic areas, because the number of gold particles per synapse displays a small but significant correlation with the total sampled area of the synapse (Fig. $7 B$ ). Most of the variance, however, would appear to represent true heterogeneity of $\alpha 7 \mathrm{nAChR}$ density at different synapses. Only $4 \%$ of all synapses were devoid of labeling at the synaptic membranes throughout all three serial sections; in all but one of these cases, other sites in the presynaptic and postsynaptic profiles were immunolabeled. Labeling in the postsynaptic cytoplasm was usually clustered and attached to membranous structures (Fig. 6G-I) often resembling the spine apparatus (Fig. 8). Gold particles were also conspicuous over nonsynaptic membranes at positions corresponding to synaptic membrane in subsequent sections, suggesting that $\alpha 7 \mathrm{nAChR}$ subunits may be localized, at least at some synapses, in a perisynaptic annulus (Fig. 5E, inset).

\section{Both type 1 and type 2 synapses show $\alpha 7$ nAChR-LIR}

Because most asymmetric synapses showed $\alpha 7$ nAChR-LIR, many of the labeled contacts are likely to be glutamatergic. Conversely, because most of the synapses in the hippocampus are 
Figure 8. Electron micrographs through anti- $\alpha 7$ nAChR-immunolabeled synapses. $A, B$, Synapses showing gold particles at the synaptic membranes (arrowhead), presynaptic vesicles (double arrowhead), and postsynaptic stacked membranous structures resembling spine apparatus (arrows). $b$, Presynaptic boutons; $s$, postsynaptic spines. Scale bar: $A, B, 200 \mathrm{~nm}$.
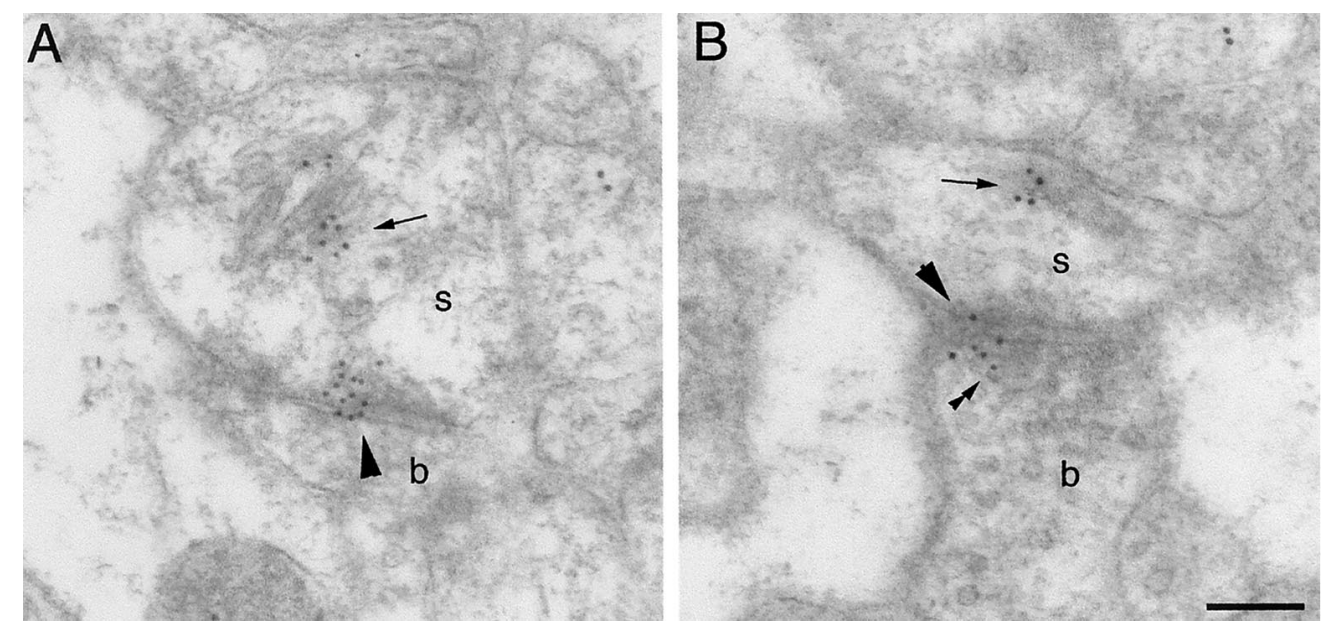
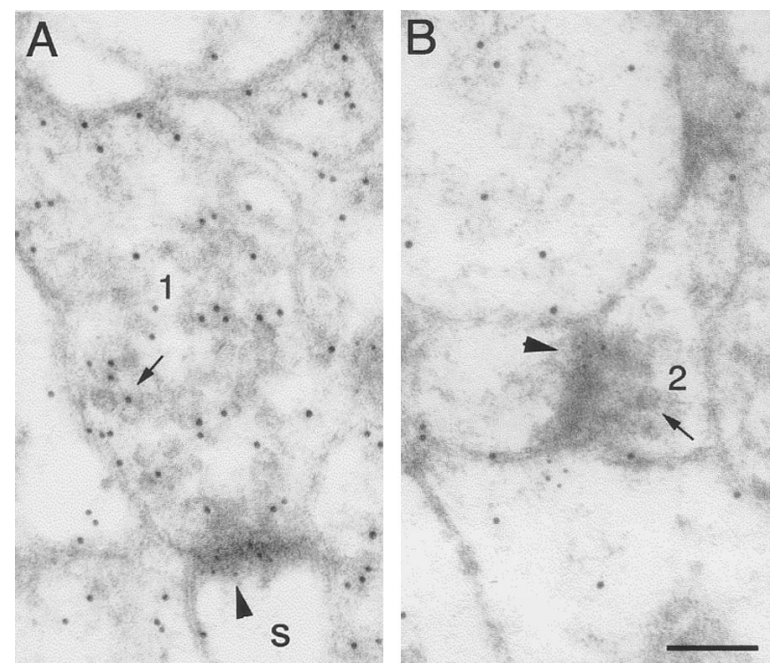

Figure 9. Glutamate $/ \alpha 7 \mathrm{nAChR}$ double labeling at CA1 stratum radiatum synapses. $A$, A glutamate-like immunoreactive synaptic terminal ( 1 , arrow, $10 \mathrm{~nm}$ particles) contacts a postsynaptic spine $(s)$. The synaptic membranes show $\alpha 7$ nAChR-LIR (arrowhead, $5 \mathrm{~nm}$ particles). $B$, A presynaptic terminal in a glutamate-labeled preparation (2) reveals no glutamate labeling at presynaptically located vesicles (arrow). The synaptic membranes, however, show labeling for $\alpha 7 \mathrm{nAChR}$ (arrowhead, $5 \mathrm{~nm}$ particles). Scale bar (shown in $B$ for $A$ and $B$ ): $190 \mathrm{~nm}$.

glutamatergic and virtually all synapses showed $\alpha 7$ nAChR-LIR, most glutamatergic synapses are likely to bear substantial levels of $\alpha 7$ nAChRs. Consistent with this interpretation, double labeling for glutamate and $\alpha 7 \mathrm{nAChR}$ shows that most but not all asymmetric $\alpha 7$ nAChR-LIR synapses are glutamate-LIR (Fig. 9); glutamate-LIR, $\alpha 7 \mathrm{nAChR}$-negative synapses were rare. Double labeling for both $\alpha 7 \mathrm{nAChRs} / \mathrm{GABA}$ and $\alpha 7 \mathrm{nAChR} /$ glutamate also revealed that most of the postsynaptic neurons with $\alpha 7$ nAChRs were glutamatergic, presumably pyramidal cells.

To investigate whether the $\alpha 7$ nAChR-immunoreactive contacts include GABAergic synapses, we performed double labeling for GABA and $\alpha 7 \mathrm{nAChRs}$. The results show that many but not all GABA-like immunoreactive profiles display $\alpha 7 \mathrm{nAChR}-\mathrm{LIR}$ at the synaptic cleft (Fig. 10), suggesting that many GABAergic synapses in CA1 stratum radiatum are subject to $\alpha 7 \mathrm{nAChR}$ mediated cholinergic modulation. It is unclear, however, whether the detailed distribution of $\alpha 7 \mathrm{nAChRs}$ at GABAergic synapses is similar to that at glutamatergic synapses.

\section{DISCUSSION}

Perhaps the most striking aspects of the current observations are the prevalence and density of $\alpha 7 \mathrm{nAChR}$ immunolabeling at synapses throughout the stratum radiatum. Almost all synaptic profiles in this region appear labeled over the synaptic membranes. Gold particles are also commonly found over presynaptic and postsynaptic elements of the synapse. The mean immunogold particle density at these $\alpha 7$ nAChR-labeled synapses (184.01 \pm 10.15 particles $/ \mu \mathrm{m}^{2}$ ) is remarkably close to the reported particle densities for NMDA and AMPA glutamate receptor labeling ( $\sim 200$ particles $/ \mu \mathrm{m}^{2}$ for each) at synapses in rat CA1 stratum radiatum of similarly prepared tissue (Racca et al., 2000). The synaptic localization of $\alpha 7$ receptors reported here is consistent with immunogold labeling in guinea pig medial prefrontal cortex (Lubin et al., 1999); there also $\alpha 7$ nAChR-LIR was detected both presynaptically and postsynaptically, at axospinous (presumably glutamatergic) synapses and at a subset of double-labeled GABAergic synapses. The presence of $\alpha 7 \mathrm{nAChR}$ immunolabeling at presynaptic terminals, although consistent with reported nicotinic stimulation of hippocampal transmitter release (see below), is in contrast to the reported absence of terminal labeling as assessed by light microscopy (Dominguez del Toro et al., 1994).

The abundance of $\alpha 7 \mathrm{nAChRs}$ at these synapses raises questions about their physiological role. Functional $\alpha 7 \mathrm{nAChR}$ subunits have been demonstrated on hippocampal interneurons, where they constitute $38 \mathrm{pS}$, inwardly rectifying channels (Shao and Yakel, 2000) mediating strong excitatory effects (Jones and Yakel, 1997; Alkondon et al., 1998; Frazier et al., 1998a,b; McQuiston and Madison, 1999; Sudweeks and Yakel, 2000) including generation of action potentials. The $\alpha 7$-mediated activation of such interneurons can result in either inhibition or disinhibition of pyramidal neurons (Ji and Dani, 2000). The presence of functional $\alpha 7$ subunits on hippocampal dentate granule or pyramidal cells has been more controversial. Activation of $\alpha 7 \mathrm{nAChRs}$ on mossy fiber presynaptic terminals has been found to increase intraterminal $\mathrm{Ca}^{2+}$ levels and to increase transmitter release (Gray et al., 1996), but others have failed to observe such $\mathrm{Ca}^{2+}$ elevation (Vogt and Regehr, 2001). Most investigators have found no nAChR-mediated excitation of pyramidal neurons (Frazier et al., 1998b), despite the presence of very low but detectable levels of $\alpha 7 \mathrm{nAChR}$ subunit mRNA in these cells by single-cell RTPCR (Sudweeks and Yakel, 2000). However, in acute and cultured hippocampal slices of 2- to 4-week-old rats, a small component of the EPSC evoked in CA1 pyramidal cells by extracellular 

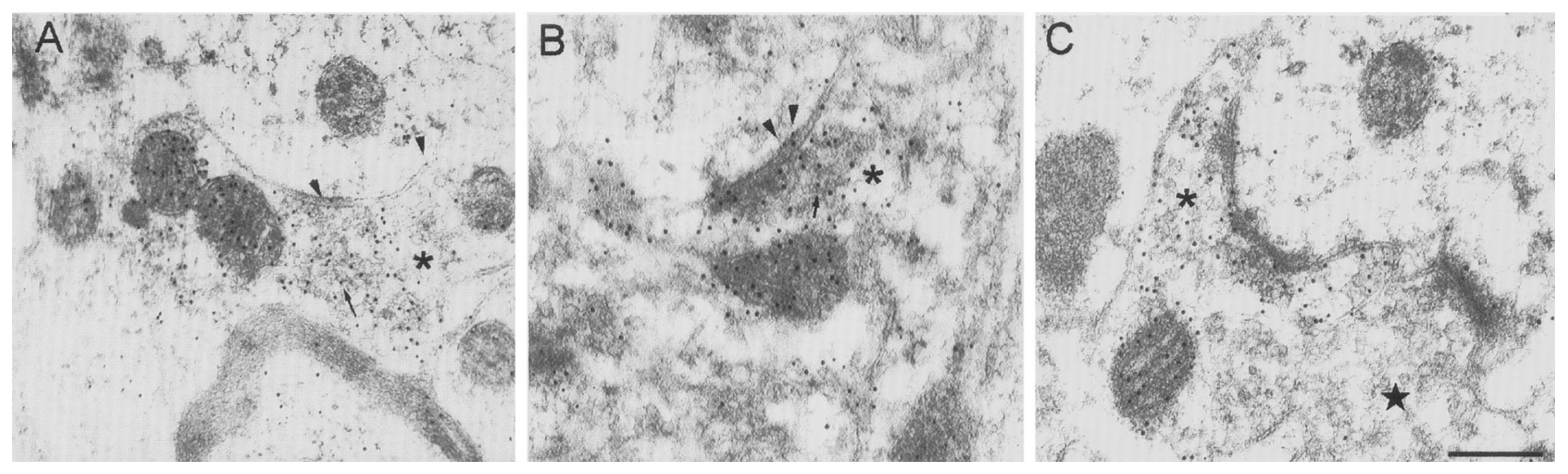

Figure 10. GABA $/ \alpha 7 \mathrm{nAChR}$ double labeling at CA1 stratum radiatum synapses. $A, B$, GABA-LIR profiles (*) with numerous $10 \mathrm{~nm}$ particles (arrows) show also $\alpha 7 \mathrm{nAChR}-\mathrm{LIR}$ at synaptic membranes (arrowheads, $5 \mathrm{~nm}$ particles). $C$, Some GABA-LIR profiles showed no $\alpha 7 \mathrm{nAChR}-\mathrm{LIR}$. Star, GABA-immunonegative presynaptic profile. Scale bar (shown in $C$ for $A-C$ ): $240 \mathrm{~nm}$.

stimulation in stratum radiatum has been reported to be $\alpha 7$ nAChR mediated (Hefft et al., 1999). The reasons for these different observations are not clear, but of some potential relevance may be the recent discovery of lynx1, an endogenous peptide homologous to $\alpha$ Bgtx that enhances nicotinic receptor currents (Miwa et al., 1999). The distribution of lynx1 binding is similar to the distribution of $\alpha 7 \mathrm{nAChRs,} \mathrm{suggesting} \mathrm{that} \mathrm{physi-}$ ological activation of $\alpha 7 \mathrm{nAChRs}$ may be modulated by the simultaneous binding of lynx1.

By producing inward, depolarizing current and particularly by directly mediating $\mathrm{Ca}^{2+}$ influx, activation of $\alpha 7 \mathrm{nAChRs}$ could be expected to influence synaptic transmission and plasticity. Presynaptic $\alpha 7 \mathrm{nAChR}$ activation, induced by repetitive, brief $(5 \times$ $200 \mathrm{msec}$ at $8.5 \mathrm{sec}$ intervals) application of $0.5 \mathrm{~mm}$ nicotine, can lead to persistent potentiation of glutamatergic synapses between dissociated hippocampal neurons (Radcliffe and Dani, 1998). $\alpha 7$ nAChR-mediated nicotinic activation in conjunction with postsynaptic depolarization has also been shown to induce LTP at glutamatergic synapses onto ventral tegmental area dopaminergic neurons. Evidence at those synapses suggested that activation of presynaptic $\alpha 7 \mathrm{nAChRs}$ most likely induced potentiation by acting presynaptically to increase the probability of glutamate release, and it was inferred that the consequent enhanced postsynaptic depolarization produced the NMDA receptor (NMDAR) activation necessary for LTP induction. There is also evidence that arachidonic acid, a putative retrograde messenger in LTP, can facilitate synaptic transmission by increasing $\alpha 7$ nAChR-mediated currents and thus enhancing presynaptic transmitter release (Nishizaki et al., 1999).

The abundance of postsynaptic $\alpha 7$ subunits revealed by our results also suggests, however, a possible postsynaptic locus for $\alpha 7$ nAChR-mediated synaptic potentiation. During early postnatal development, when AMPA receptors are absent from many postsynaptic membranes, the $\alpha 7$ nAChRs may actually mediate the induction of LTP, either directly or in conjunction with NMDARs. During this time, levels of $\alpha 7 \mathrm{nAChRs}$ in many brain areas, including hippocampus (Hunt and Schmidt, 1979) and somatosensory cortex (Bina et al., 1995), are much higher than in the adult. Activation of postsynaptic, particularly perisynaptic, $\alpha 7$ subunits, especially during the first postnatal week when their density is presumably highest, could depolarize a dendritic spine sufficiently to relieve the voltage-dependent $\mathrm{Mg}^{2+}$ block of simultaneously stimulated NMDA receptors, thereby inducing
NMDA-dependent synaptic plasticity. Indeed, a selective $\alpha 7$ nAChR-mediated enhancement of the NMDA component of EPSPs recorded from auditory cortex pyramidal neurons is seen at postnatal day 8-16 but not in older rats (Aramakis and Metherate, 1998). The high $\mathrm{Ca}^{2+}$ permeability of $\alpha 7 \mathrm{nAChRs}$ (Bertrand et al., 1993; Seguela et al., 1993; Castro and Albuquerque, 1995) raises the further possibility that activation of these receptors alone could yield sufficient $\mathrm{Ca}^{2+}$ influx to trigger calcium-dependent processes, including the induction of synaptic plasticity (Ghosh and Greenberg, 1995). The likelihood of $\alpha 7$ nAChR-driven synaptic potentiation might be enhanced if the resulting spine depolarization were sufficient to activate voltagegated calcium channels in the spine membrane (Yuste and Denk, 1995; Reid et al., 2001), or if the resulting $\mathrm{Ca}^{2+}$ influx were amplified by calcium-induced calcium release (CICR) from internal stores in the dendritic spine (Emptage et al., 1999); indeed, there is evidence for nicotinic activation of CICR (Emptage et al., 2001). Such mechanisms may not be essential for gross brain development, because transgenic mice lacking the $\alpha 7$ subunit displayed no abnormalities of brain anatomy (Orr-Urtreger et al., 1997) or of behavior (Paylor et al., 1998). However, chronic systemic nicotine administration during the second week of postnatal development has recently been found to lead to persistent electrophysiological abnormalities in auditory neocortex (Aramakis et al., 2000). It is known that $\alpha 7 \mathrm{nAChRs}$ activate and desensitize rapidly in response to brief exposure to high $\mathrm{ACh}$ concentrations (Couturier et al., 1990); the half-maximal concentrations for $\alpha 7$ activation and inactivation of this subunit under physiological conditions appear to be in the range of 30-90 and 1-2 $\mu \mathrm{M}$, respectively (Seguela et al., 1993; Fenster et al., 1997). Choline, the product of ACh hydrolysis in the extracellular space, is a selective $\alpha 7 \mathrm{nAChR}$ agonist (Alkondon et al., 1997), and ambient levels of choline in the CSF caused by hydrolysis of ACh may be, after strong cholinergic activity, sufficiently high to activate and/or to desensitize $\alpha 7$ receptors (Papke et al., 1996). The half-maximal desensitization concentration is sufficiently high, however, for a large fraction of the receptors to remain functional under normal conditions (McGehee et al., 1995; Gray et al., 1996). The physiological consequence of these differential sensitivities is unclear, but it could provide a form of lateral inhibition in time and space: $\mathrm{ACh}$ release from an activated cholinergic terminal could result in $\alpha 7$-mediated facilitation of synaptic transmission and plasticity at simultaneously activated glutamatergic 
synapses close to the activated terminal where the local ACh concentration would transiently be high. As a result of diffusion, synapses farther from the cholinergic terminal, or nearby synapses activated asynchronously, would experience inactivating ACh concentrations.

In addition to labeling of synaptic membranes, we also observed abundant labeling over endoplasmic reticulum and over membranous structures in the postsynaptic cytoplasm, including the spine apparatus (Figs. 5-7). This pattern resembles the reported association of $\beta 2$ and $\alpha 4 \mathrm{nAChRs}$ with endoplasmic reticulum and transport vesicles in various neurons, including neocortical pyramidal cells (Hill et al., 1993; Nakayama et al., 1995). These observations of a large pool of intracellular $\alpha 7$ nAChRs suggest that these subunits may be actively internalized or inserted and that the extracellular, functional receptors may thus be dynamically regulated in response to the ongoing activity of the neuron.

Finally, the near-ubiquitous presence of $\alpha 7 \mathrm{nAChRs}$ at hippocampal synapses described here renders more salient the recent report (Wang et al., 2000b) of high-affinity binding of $\beta$-amyloid peptide $\left(\mathrm{A} \beta_{1-42}\right)$ to $\alpha 7 \mathrm{nAChRs}$. Submicromolar concentrations of soluble $\mathrm{A} \beta_{1-42}$, like its fibrillar amyloid precipitate, may be neurotoxic (Roher et al., 1996); toxicity can be partially blocked by nicotine (Wang et al., 2000a). Furthermore, similarly low concentrations of $\mathrm{A} \beta_{1-42}$ can block $\alpha 7$ nAChR-mediated currents in hippocampal interneurons (Pettit et al., 2001). Thus the widespread distribution of $\alpha 7 \mathrm{nAChRs}$ in the hippocampus and their interactions with $\mathrm{A} \beta_{1-42}$ peptide may be important factors in early cognitive impairments and later neuronal loss in Alzheimer's disease.

\section{REFERENCES}

Alkondon M, Pereira EF, Cortes WS, Maelicke A, Albuquerque EX (1997) Choline is a selective agonist of alpha7 nicotinic acetylcholine receptors in the rat brain neurons. Eur J Neurosci 9:2734-2742.

Alkondon M, Pereira EFR, Albuquerque EX (1998) $\alpha$-Bungarotoxinand methyllycaconitine-sensitive nicotinic receptors mediate fast synaptic transmission in interneurons of rat hippocampal slices. Brain Res 810:257-263.

Aramakis VB, Metherate R (1998) Nicotine selectively enhances NMDA receptor-mediated synaptic transmission during postnatal development in sensory neocortex. J Neurosci 18:8485-8495.

Aramakis VB, Hsieh CY, Leslie FM, Metherate R (2000) A critical period for nicotine-induced disruption of synaptic development in rat auditory cortex. J Neurosci 20:6106-6116.

Arimatsu Y, Seto A, Amano T (1978) Localization of alphabungarotoxin binding sites in mouse brain by light and electron microscopic autoradiography. Brain Res 147:165-169.

Aztiria EM, Sogayar MC, Barrantes FJ (2000) Expression of a neuronal nicotinic acetylcholine receptor in insect and mammalian host cell systems. Neurochem Res 25:171-180.

Barrantes GE, Rogers AT, Lindstrom J, Wonnacott S (1995) alphaBungarotoxin binding sites in rat hippocampal and cortical cultures: initial characterisation, colocalisation with alpha 7 subunits and upregulation by chronic nicotine treatment. Brain Res 672:228-236.

Bertrand D, Galzi JL, Devilliers-Thiéry A, Bertrand S, Changeux JP (1993) Mutation at two distinct sites within the channel domain M2 alter calcium permeability of the neuronal alpha7 nicotinic receptor. Proc Natl Acad Sci USA 90:6971-6975.

Bina KG, Guzman P, Broide RS, Leslie FM, Smith MA, O'Dowd DK (1995) Localization of alpha 7 nicotinic receptor subunit mRNA and alpha-bungarotoxin binding sites in developing mouse somatosensory thalamocortical system. J Comp Neurol 363:321-332.

Castro NG, Albuquerque EX (1995) $\alpha$-Bungarotoxin-sensitive hippocampal nicotinic receptor channel has a high calcium permeability. Biophys J 68:516-524.

Chen D, Patrick JW (1997) The alpha-bungarotoxin-binding nicotinic acetylcholine receptor from rat brain contains only the alpha7 subunit. J Biol Chem 272:24024-24029.

Chen D, Dang H, Patrick JW (1998) Contributions of N-linked glycosylation to the expression of a functional alpha7-nicotinic receptor in Xenopus oocytes. J Neurochem 70:349-357.
Chu ZG, Zhou FM, Hablitz JJ (2000) Nicotinic acetylcholine receptormediated synaptic potentials in rat neocortex. Brain Res 887:399-405.

Colonnier M (1968) Synaptic patterns on different cell types in the different laminae of the cat visual cortex. An electron microscope study. Brain Res 9:268-287.

Couturier S, Bertrand D, Matter JM, Hernandez MC, Bertrand S, Millar N, Valera S, Barkas T, Ballivet M (1990) A neuronal nicotinic acetylcholine receptor subunit (alpha 7) is developmentally regulated and forms a homo-oligomeric channel blocked by alpha-BTX. Neuron 5:847-856.

Dominguez del Toro E, Juiz JM, Peng X, Lindstrom J, Criado M (1994) Immunocytochemical localization of the alpha 7 subunit of the nicotinic acetylcholine receptor in the rat central nervous system. J Comp Neurol 349:325-342.

Dudai Y, Segal M (1978) alpha-Bungarotoxin binding sites in rat hippocampus: localization in postsynaptic cells. Brain Res 154:167-171.

Emptage N, Bliss TV, Fine A (1999) Single synaptic events evoke NMDA receptor-mediated release of calcium from internal stores in hippocampal dendritic spines. Neuron 22:115-124.

Emptage N, Reid CA, Fine A (2001) Calcium stores in hippocampal synaptic boutons mediate short term plasticity, store-operated $\mathrm{Ca} 2+$ entry and spontaneous transmitter release. Neuron 29:197-208.

Fenster CP, Rains MF, Noerager B, Quick MW, Lester RA (1997) Influence of subunit composition on desensitization of neuronal acetylcholine receptors at low concentrations of nicotine. J Neurosci 17:5747-5759.

Frazier CJ, Buhler AV, Weiner JL, Dunwiddie TV (1998a) Synaptic potentials mediated via alpha-bungarotoxin-sensitive nicotinic acetylcholine receptors in rat hippocampal interneurons. J Neurosci 18:8228-8235.

Frazier CJ, Rollins YD, Breese CR, Leonard S, Freedman R, Dunwiddie TV (1998b) Acetylcholine activates an $\alpha$-bungarotoxin-sensitive nicotinic current in rat hippocampal interneurons, but not pyramidal cells. J Neurosci 18:1187-1195.

Fujii S, Ji Z, Sumikawa K (2000) Inactivation of alpha7 ACh receptors and activation of non-alpha7 ACh receptors both contribute to long term potentiation induction in the hippocampal CA1 region. Neurosci Lett 286:134-138.

Ghosh A, Greenberg ME (1995) Calcium signalling in neurons: molecular mechanisms and cellular consequences. Science 268:239-247.

Gray EG (1959) Axo-somatic and axo-dendritic synapses of the cerebral cortex: an electron microscope study. J Anat 93:420-433.

Gray R, Rajan AS, Radcliffe KA, Yakehiro M, Dani JA (1996) Hippocampal synaptic transmission enhanced by low concentrations of nicotine. Nature 383:713-716.

Hefft S, Hulo S, Bertrand D, Muller D (1999) Synaptic transmission at nicotinic acetylcholine receptors in rat hippocampal organotypic cultures and slices. J Physiol (Lond) 515:769-776.

Hill JAJ, Zoli M, Bourgeois JP, Changeux JP (1993) Immunocytochemical localization of a neuronal nicotinic receptor: the beta 2 -subunit. J Neurosci 13:1551-1568.

Hunt S, Schmidt J (1979) The relationship of alpha-bungarotoxin binding activity and cholinergic termination within the rat hippocampus. Neuroscience 4:585-592.

Hunt SP, Schmidt J (1978) The electron microscopic autoradiographic localization of alpha-bungarotoxin binding sites within the central nervous system of the rat. Brain Res 142:152-159.

Hunter BE, de Fiebre CM, Papke RL, Kem WR, Meyer EM (1994) A novel nicotinic agonist facilitates induction of long-term potentiation in the rat hippocampus. Neurosci Lett 168:130-134.

Ji D, Dani JA (2000) Inhibition and disinhibition of pyramidal neurons by activation of nicotinic receptors on hippocampal interneurons. J Neurophysiol 83:2682-2690.

Jones S, Yakel JL (1997) Functional nicotinic ACh receptors on interneurons in the rat hippocampus. J Physiol (Lond) 504:603-610.

Lena C, Changeux J-P, Mulle C (1993) Evidence for "preterminal" nicotinic receptors on GABAergic axons in the rat interpeduncular nucleus. J Neurosci 13:2680-2688.

Levin ED, Rezvani AH (2000) Development of nicotinic drug therapy for cognitive disorders. Eur J Pharmacol 393:141-146.

Liang SD, Vizi ES (1997) Positive feedback modulation of acetylcholine release from isolated rat superior cervical ganglion. J Pharmacol Exp Ther 280:650-655.

Løvtrup S, Zelander T (1962) Isolation of brain mitochondria. Exp Cell Res 27:468-473.

Lubin M, Erisir A, Aoki C (1999) Ultrastructural immunolocalization of the $\alpha 7 \mathrm{nAChR}$ subunit in guinea pig medial prefrontal cortex. Ann NY Acad Sci 868:628-632.

Mansvelder HD, McGehee DS (2000) Long-term potentiation of excitatory inputs to brain reward areas by nicotine. Neuron 27:349-357.

Matsubara A, Laake JH, Davanger S, Usami S, Ottersen OP (1996) Organization of AMPA receptor subunits at a glutamate synapse: a quantitative immunogold analysis of hair cell synapses in the rat organ of Corti. J Neurosci 16:4457-4467.

McGehee DS, Heath MJ, Gelber S, Devay P, Role LW (1995) Nicotine 
enhancement of fast excitatory synaptic transmission in CNS by presynaptic receptors. Science 269:1692-1696.

McQuiston AR, Madison DV (1999) Nicotinic receptor activation excites distinct subtypes of interneurons in the rat hippocampus. J Neurosci 19:2887-2896.

Miwa JM, Ibañez-Tallon I, Crabtree GW, Sánchez R, Sali A, Role LW, Heintz N (1999) lynx1, an endogenous toxin-like modulator of nicotinic acetylcholine receptors in the mammalian CNS. Neuron 23:105-114.

Nakayama H, Shioda S, Okuda H, Nakashima T, Nakai Y (1995) Immunocytochemical localization of nicotinic acetylcholine receptor in rat cerebral cortex. Brain Res Mol Brain Res 32:321-328.

Nishizaki T, Nomura T, Matsuoka T, Enikolopov G, Sumikawa K (1999) Arachidonic acid induces a long-lasting facilitation of hippocampal synaptic transmission by modulating PKC activity and nicotinic ACh receptors. Brain Res Mol Brain Res 69:263-272.

Orr-Urtreger A, Göldner FM, Saeki M, Lorenzo I, Goldberg L, De Biasi M, Dani JA, Patrick JW, Beaudet AL (1997) Mice deficient in the $\alpha 7$ neuronal nicotinic acetylcholine receptor lack $\alpha$-bungarotoxin binding sites and hippocampal fast nicotinic currents. J Neurosci 17:9165-9171.

Papke RL, Bencherif M, Lippiello P (1996) An evaluation of neuronal nicotinic acetylcholine receptor activation by quaternary nitrogen compounds indicates that choline is selective for the alpha 7 subtype. Neurosci Lett 213:201-204.

Paylor R, Nguyen M, Crawley JN, Patrick J, Beaudet A, Orr-Urtreger A (1998) Alpha7 nicotinic receptor subunits are not necessary for hippocampal-dependent learning or sensorimotor gating: a behavioral characterization of Acra7-deficient mice. Learn Mem 5:302-316.

Pettit DL, Shao Z, Yakel JL (2001) $\beta$-Amyloid1-42 peptide directly modulates nicotinic receptors in the rat hippocampal slice. J Neurosci 21:RC120.

Racca C, Stephenson FA, Streit P, Roberts JD, Somogyi P (2000) NMDA receptor content of synapses in stratum radiatum of the hippocampal CA1 area. J Neurosci 20:2512-2522.

Radcliffe KA, Dani JA (1998) Nicotinic stimulation produces multiple forms of increased glutamatergic synaptic transmission. J Neurosci 18:7075-7083.

Radcliffe KA, Fisher JL, Gray R, Dani JA (1999) Nicotinic modulation of glutamate and GABA synaptic transmission of hippocampal neurons. Ann NY Acad Sci 868:591-610.

Rapier C, Lunt GG, Wonnacott S (1988) Stereoselective nicotineinduced release of dopamine from striatal synaptosomes: concentration dependence and repetitive stimulation. J Neurochem 50:1123-1130.

Reid CA, Fabian-Fine R, Fine A (2001) Postsynaptic calcium transients evoked by activation of individual hippocampal mossy fiber synapses. J Neurosci 21:2206-2214.

Roerig B, Nelson DA, Katz LC (1997) Fast synaptic signaling by nicotinic acetylcholine and serotonin 5-HT3 receptors in developing visual cortex. J Neurosci 17:8353-8362.

Roher AE, Chaney MO, Kuo YM, Webster SD, Stine WB, Haverkamp LJ, Woods AS, Cotter RJ, Tuohy JM, Krafft GA, Bonnell BS, Emmerling MR (1996) Morphology and toxicity of Abeta-(1-42) dimer derived from neuritic and vascular amyloid deposits of Alzheimer's disease. J Biol Chem 271:20631-20635.

Role LW, Berg DK (1996) Nicotinic receptors in the development and modulation of CNS synapses. Neuron 16:1077-1085.
Schägger H, von Jagow G (1987) Tricine-sodium dodecyl sulfatepolyacrylamide gel electrophoresis for the separation of proteins in the range from 1 to $100 \mathrm{kDa}$. Anal Biochem 166:368-379.

Schoepfer R, Conroy WG, Whiting P, Gore M, Lindstrom J (1990) Brain alpha-bungarotoxin binding protein cDNAs and mAbs reveal subtypes of this branch of the ligand-gated ion channel gene superfamily. Neuron 5:35-48.

Segal M, Dudai Y, Amsterdam A (1978) Distribution of an $\alpha$-bungarotoxin-binding cholinergic nicotinic receptor in rat brain. Brain Res 148:105-119.

Seguela P, Wadiche J, Dineley-Miller K, Dani JA, Patrick JW (1993) Molecular cloning, functional properties, and distribution of rat brain alpha 7: a nicotinic cation channel highly permeable to calcium. J Neurosci 13:596-604.

Shao Z, Yakel JL (2000) Single channel properties of neuronal nicotinic $\mathrm{ACh}$ receptors in stratum radiatum interneurons of rat hippocampal slices. J Physiol (Lond) 527:507-513.

Somogyi P, Takagi H (1982) A note on the use of picric acidparaformaldehyde-glutaraldehyde fixative for correlated light and electron microscopic immunocytochemistry. Neuroscience 7:1779-1783.

Sudweeks SN, Yakel JL (2000) Functional and molecular characterization of neuronal nicotinic ACh receptors in rat CA1 hippocampal neurons. J Physiol (Lond) 527:515-528.

Vidal C, Changeux J-P (1993) Nicotinic acid and muscarinic modulations of excitatory synaptic transmission in the rat prefrontal cortex in vitro. Neuroscience 56:23-32.

Vogt KE, Regehr WG (2001) Cholinergic modulation of excitatory synaptic transmission in the CA3 area of the hippocampus. J Neurosci 21:75-83.

Wang HY, Lee DH, D'Andrea MR, Peterson PA, Shank RP, Reitz AB (2000a) beta-Amyloid(1-42) binds to alpha7 nicotinic acetylcholine receptor with high affinity. Implications for Alzheimer's disease pathology. J Biol Chem 275:5626-5632.

Wang HY, Lee DH, Davis CB, Shank RP (2000b) Amyloid peptide Abeta(1-42) binds selectively and with picomolar affinity to alpha7 nicotinic acetylcholine receptors. J Neurochem 75:1155-1161.

Wessler I, Apel C, Garmsen M, Klein A (1992) Effects of nicotine receptor agonists on acetylcholine release from the isolated motor nerve, small intestine and trachea of rats and guinea-pigs. Clin Invest 70:182-189.

Wiedenmann B, Franke WW (1985) Identification and localization of synaptophysin, an integral membrane glycoprotein of MW 38,000 characteristic of presynaptic vesicles. Cell 41:1017-1028.

Wonnacott S (1997) Presynaptic nicotinic ACh receptors. Trends Neurosci 20:92-98.

Yuste R, Denk W (1995) Dendritic spines as basic functional units of neuronal integration. Nature 375:682-684.

Zarei MM, Radcliffe KA, Chen D, Patrick JW, Dani JA (1999) Distributions of nicotinic acetylcholine receptor alpha 7 and beta 2 subunits on cultured hippocampal neurons. Neuroscience 88:755-764.

Zhang M, Wang YT, Vyas DM, Neuman RS, Bieger D (1993) Nicotinic cholinoceptor-mediated excitatory postsynaptic potentials in rat nucleus ambiguus. Exp Brain Res 96:83-88. 